\title{
DALUWARSA DALAM PENUNTUTAN PIDANA PERSPEKTIF HUKUM PIDANA ISLAM
}

\author{
Firdaus $\quad$ Rumah Sakit Islam Jemursari \\ yurizvit72@gmail.com Jl. Raya Jemursari 81-87 Surabaya
}

\begin{abstract}
This article discusses the different point of view among the Muslim scholars about whether expired can abolish the punishment or not according to Islamic criminal law. Majority of Muslim scholars view that it cannot abolish the punishment. For those who hold the principle of expiry, they do not consider it as a penalty cancellation for entire jarîmah. Islamic law sees expired is only included to cancel the right to carry out the sentence. Thus, in the perspective of Islamic criminal law, any persons who have committed a crime and it has not yet sentenced and has already expired, it does not mean that the criminal is not removed. This means that a person who commits criminal act and it is prosecuted at any times, so the case can be tried. While the expired is valid only when the crime carried out by someone has got the judge's ruling, so that the perpetrator is serving as the judge ousted.

Keywords: Expired, criminal prosecution, Islamic Criminal Law.
\end{abstract}

Abstrak: Artikel ini membahas tentang daluarsa dalam penuntutan pidana perspektif hukum pidana Islam. Dalam hukum pidana Islam, di kalangan Ulama masih diperselisihkan, apakah daluwarsa dapat menghapuskan hukuman atau tidak. Menurut kebanyakan fuqaha, daluarsa tidak menghapuskan hukuman bagi seluruh jarîmah. Daluwarsa hanya masuk dalam bagian yang menghapuskan hak untuk melaksanakan hukuman. Dengan demikian, dalam perspektif hukum pidana Islam, setiap orang yang telah melakukan tindak pidana dan terhadap perbuatan pidana itu belum sampai dijatuhi hukuman, maka meskipun sudah daluwarsa, pidana tidak menjadi hapus. Ini berarti orang yang melakukan tindak pidana kapan waktu saja dapat dituntut atau perkaranya dapat diadili. Sedangkan daluwarsa hanya berlaku manakala tindak pidana yang telah dilakukan seseorang itu telah mendapat putusan hakim sehingga orang tersebut harus menjalani hukuman sebagaimana yang telah dijatuhkan hakim.

Kata Kunci: Daluarsa, penuntutan pidana, hukum pidana Islam. 


\section{Pendahuluan}

Daluwarsa adalah lewatnya waktu yang menjadi sebab gugurnya atau hapusnya hak untuk menuntut atau melaksanakan hukuman terhadap seseorang yang melakukan tindak pidana. Dalam perspektif KUHP bahwa pada dasarnya semua pelaku (dalam arti luas) dari suatu tindak pidana harus dituntut di muka sidang pengadilan pidana, akan tetapi baik secara umum maupun secara khusus Undang-Undang menentukan peniadaan dan atau penghapusan penuntutan dalam hal-hal tertentu, misalnya dalam pasal 78 KUHP bahwa hak menuntut pidana hapus karena daluwarsa. ${ }^{1}$ Hal ini sebagaimana dipertegas dalam pasal 78 KUHP bahwa hak menuntut pidana hapus karena daluwarsa. ${ }^{2}$

Hak menuntut pidana menjadi hapus karena lewatnya waktu (78 ayat 1). Dasar dari ketentuan ini sama dengan dasar dari ketentuan pasal 76 ayat (1) tentang asas ne bis in indem ialah untuk kepastian hukum bagi setiap kasus pidana, agar si pembuatnya tidak selama-lamanya ketentraman hidupnya diganggu tanpa batas waktu oleh ancaman penuntutan oleh negara, pada suatu waktu gangguan seperti itu harus diakhiri. Orang yang berdosa karena melakukan tindak pidana, untuk menghindari penuntutan oleh negara, mengharuskan dia untuk selalu bersikap waspada kepada setiap orang, bersembunyi, menghindari pergaulan umum yang terbuka, semua itu membuat ketidaktenangan hidupnya. Ketidaktenangan hidup yeng sekian lama sebelum masa daluwarsa berakhir pada dasarnya adalah suatu penderitaan jiwa, yang tidak berbeda dengan penderitaan akibat menjalani suatu pidana yang dijatuhkan oleh pengadilan. ${ }^{3}$

Selain alasan untuk kepastian hukum, maka prinsip lewatnya waktu, juga didasarkan pada faktor kesulitan dalam hal untuk untuk mengungkap kasus perkara. Mengajukan tuntutan pidana pada dasarnya adalah berupa pekerjaan mengungkap suatu peristiwa sebagaiman kejadian senyatanya atau yang sebenarnya (nateriele waarheid) pada waktu kejadian yang sudah berlalu. Pengungkapan peristiwa itu memerlukan bukti-bukti yang ditentukan oleh Undang-Undang, baik mengenai macam-macamnya maupun cara dan sistem penggunaannya. Semakin lama lewatnya waktu akan semakin sulit untuk memperoleh

1 E.Y. Knter dan Sianturi, Asas-Asas Hukum Pidana di Indonesia dan Penerapannya (Jakarta: Alumni, 1982), 426.

${ }^{2}$ Moeljatno, Kitab Undang-Undang Hukum Pidana (Jakarta: Bumi Aksara, 2003), 33.

${ }^{3}$ Adam Chazawi, Pelajaran Hukum Pidana Bagian 2(Jakarta: PT Raja Grafindo Persada, 2002), 173. 
alat-alat bukti tersebut. Semakin lama ingatan seorang saksi akan semakin berkurang bahkan lenyap atau lupa tentang suatu kejadian yang dilihatnya atau yang dialaminya. Demikian juga benda-benda bukti, dengan waktu yang akan menyebabkan benda itu musnah atau hilang dan tidak ada lagi. Dengan berlalunya waktu yang lama akan memperkecil keberhasilan, bahkan dapat menyebabkan kegagalan dari suatu pekerjaan penuntutan. ${ }^{4}$

Satu hal lagi yang penting adalah dengan lewatnya waktu, penderitaan batin, baik bagi korban dan keluarganya, maupun masyarakat sebagai akibat dari suatu tindak pidana akan semakin berkurang yang pada akhirnya akan lenyap atau lupa dari ingatan. Jika dilihat dari teori pembalasan, menjadi tidak penting lagi untuk mengungkap suatu kasus-kasus yang sudah dilupakan oleh masyarakat. Walaupun zaman modern, sekarang teori pembalasan dinilai oleh banyak kalangan suda kuno, namun pada kenyataannya kepuasan korban dan masyarakat atas pidana yang dijatuhkan pengadilan tidak dapat terlepas dari berat ringannya (setimpal) dari kesalahan dan berat ringannya tindak pidana yang dilakukannya. ${ }^{5}$

Berapa lamakah tenggang lewatnya waktu seorang pelaku tindak pidana untuk menjadi tidak dapat dituntut karena daluwarsa? Dalam hal ini tergantung dari berat ringannya pidana yang diancamkan pada tindak pidana yang diperbuat. Hal ini tampak pada ketentuan pasal 78 ayat (1), yang menetapkan, bahwa hak menuntut pidana menjadi gugur dalam tenggang waktu, ${ }^{6}$ yakni:

a. Untuk semua tindak pidana pelanggaran dan kejahatan yang dilakukan dengan percetakan, sesudah satu tahun;

b. Untuk tindak pidana kejahatan yang diancam pidana denda, pidana kurungan atau pidana penjara paling lama tiga tahun, sesudah enam tahun;

c. Untuk tindak pidana kejahatan yang diancam dengan pidana lebih dari tiga tahun, sesudah dua belas tahun; dan

d. Untuk tindak pidana kejahatan yang diancam dengan pidana mati atau pidana penjara seumur hidup atau pidana penjara sementara setinggi-tingginya dua puluh tahun, sesudah delapan belas tahun.

\footnotetext{
${ }^{4}$ Ibid., 173.

${ }^{5}$ Ibid., 173.

${ }^{6}$ Moeljatno, Kitab Undang-Undang Hukum Pidana, 33.
} 
Dalam hukum pidana Islam, di kalangan fuqaha masih diperdebatkan, apakah daluwarsa dapat menghapus hukuman atau tidak. Menurut kebanyakan fuqaha, tidak menghapuskan. Bagi fuqaha yang memakai prinsip daluwarsa tersebut, tidak menganggapnya sebagai faktor pembatalan hukuman bagi seluruh jarîmah. Dalam hal ini ada dua pendapat: Pendapat pertama, dari Imam Malik, Syafi'i dan Ahmad. Menurut ketiga imam tersebut sesuatu hukuman atau jarîmah tidak gugur, bagaimanapun juga lamanya hukuman atau jarîmah tersebut tanpa dilaksanakan atau diadili, selama bukan berupa hukuman atau jarîmah ta'zîr. Pendapat kedua, berdasar dari Imam Abu Hanifah beserta murid-muridnya. Pada dasarnya, pendapat mereka sama dengan pendapat pertama, yaitu mengakui adanya prinsip daluwarsa untuk jarîmah-jarîmah ta’zîr, jarîmah-jarîmah qishâsh-diyat dan satu jarîmah hudûd, yaitu memfitnah (qadzaf).

Berdasarkan keterangan tersebut artikel ini membahas tentang daluwarsa dalam hukum Islam.

\section{Pengertian dan Dasar Hukum Daluwarsa}

Daluwarsa adalah lewatnya waktu yang menjadi sebab gugurnya atau hapusnya hak untuk menuntut atau melaksanakan hukuman terhadap seseorang yang melakukan tindak pidana. Dalam perspektif KUHP, pada dasarnya semua pelaku (dalam arti luas) dari suatu tindak pidana harus dituntut di muka sidang pengadilan pidana, akan tetapi baik secara umum atau secara khusus undang-undang menentukan peniadaan dan atau penghapusan penuntutan dalam hal-hal tertentu, misalnya karena daluwarsa. ${ }^{8} \mathrm{Hal}$ ini sebagaimana ditegaskan dalam Pasal 78 KUHP bahwa hak menuntut pidana hapus karena daluwarsa.

Dasar dari ketentuan tersebut sama dengan dasar dari ketentuan pasal 76 ayat (1) tentang asas ne bis in idem ialah untuk kepastian hukum bagi setiap kasus pidana, agar si pembuatnya tidak selamalamanya ketenteraman hidupnya diganggu tanpa batas waktu oleh ancaman penuntutan oleh negara, pada suatu waktu gangguan seperti itu harus diakhiri. Orang yang berdosa karena melakukan tindak pidana, untuk menghindari penuntutan oleh negara, mengharuskan dia untuk

\footnotetext{
${ }^{7}$ Ahmad Hanafi, Asas-Asas Hukum Pidana Islam (Jakarta: Bulan Bintang, 1986), 394.

8 E.Y. Kanter dan Sianturi, Asas-Asas Hukum Pidana di Indonesia dan Penerapannya (Jakarta: Alumni, 1982), 426.

${ }_{9}^{9}$ Moeljatno, Kitab Undang-Undang Hukum Pidana, 33.
} 
selalu bersikap waspada kepada setiap orang, bersembunyi, menghindari pergaulan umum yang terbuka, semua itu membuat ketidaktenangan hidupnya. Ketidaktenangan hidup yang sekian lama sebelum masa daluwarsa berakhir pada dasarnya adalah suatu penderitaan jiwa, yang tidak berbeda dengan penderitaan akibat menjalani suatu pidana yang dijatuhkan oleh pengadilan. ${ }^{10}$

Selain alasan untuk kepastian hukum, prinsip lewatnya waktu ini, juga didasarkan pada faktor kesulitan dalam hal untuk mengungkap kasus perkara. Mengajukan tuntutan pidana pada dasarnya adalah berupa pekerjaan mengungkap suatu peristiwa sebagaimana kejadian senyatanya (materiele waarheid) pada waktu kejadian yang sudah berlalu. Pengungkapan peristiwa itu memerlukan bukti-bukti yang ditentukan dan diatur menurut ketentuan Undang-undang, baik mengenai macammacamnya maupun cara dan sistem penggunaannya. Semakin lama lewatnya waktu akan semakin sulit untuk memperoleh alat-alat bukti tersebut. Semakin lama ingatan seorang saksi akan semakin berkurang bahkan lenyap atau lupa tentang suatu kejadian yang dilihatnya atau dialaminya. Demikian juga benda-benda bukti, dengan waktu yang lama akan menyebabkan benda itu menjadi musnah atau hilang dan tidak ada lagi. Dengan berlalunya waktu yang lama memperkecil keberhasilan bahkan dapat menyebabkan kegagalan dari suatu pekerjaan penuntutan.

Satu hal lagi yang penting ialah dengan lewatnya waktu, penderitaan batin, baik bagi korban dan keluarganya maupun masyarakat sebagai akibat dari suatu tindak pidana, akan semakin berkurang yang pada akhirnya akan lenyap atau lupa dari ingatan. Jika dilihat dari teori pembalasan, menjadi tidak penting lagi untuk mengungkap suatu kasus yang sudah dilupakan oleh masyarakat. Walaupun zaman modern sekarang teori pembalasan dinilai oleh banyak kalangan sudah kuno, namun masih menjadi bahan pertimbangan hukum. ${ }^{2}$

Dasar hukum hapusnya hak menuntut pidana karena daluwarsa diatur dalam pasal 78 sampai dengan pasal $81 \mathrm{KUHP} .{ }^{13}$

\footnotetext{
${ }^{10}$ Adami Chazawi, Pelajaran Hukum Pidana Bagian 2, 173.

11 lbid., 173.

${ }^{12}$ E.Y. Kanter dan Sianturi, Asas-Asas Hukum Pidana di Indonesia dan Penerapannya, 427.

${ }^{13}$ Moeljatno, Kitab Undang-Undang Hukum Pidana, 33.
} 


\section{Daluwarsa Hak Penuntutan Pidana dalam KUHP}

Berapa lamakah tenggang lewatnya waktu pelaku tindak pidana untuk menjadi tidak dapat dituntut karena daluwarsa? Dalam hal ini bergantung dari berat ringannya pidana yang diancamkan pada tindak pidana yang diperbuat. Hal ini tampak pada ketentuan pasal 78 ayat (1), yang menetapkan, bahwa hak menuntut pidana menjadi hapus karena lewat waktu ${ }^{14}$ yakni:

a. untuk semua tindak pidana pelanggaran dan kejahatan yang dilakukan dengan percetakan, sesudah satu tahun;

b. untuk tindak pidana kejahatan yang diancam dengan pidana denda, pidana kurungan atau pidana penjara paling lama tiga tahun, sesudah enam tahun;

c. untuk tindak pidana kejahatan yang diancam dengan pidana penjara lebih dari tiga tahun, sesudah dua belas tahun; dan

d. untuk tindak pidana kejahatan yang diancam dengan pidana mati atau pidana penjara seumur hidup atau pidana penjara sementara setinggi-tingginya dua puluh tahun, sesudah delapan belas tahun.

Sedangkan untuk pelaku anak-anak yang pada saat melakukan tindak pidana umurnya belum delapan belas tahun, menurut ayat (2) maka tenggang daluwarsa hapusnya penuntutan pidana adalah dikurangi sepertiga dari ketentuan pada ayat pertamanya. ${ }^{15}$

Menetapkan lamanya tenggang daluwarsa untuk peniadaan penuntutan pidana yang didasarkan pada berat ringannya ancaman pidana atau berat ringannya tindak pidana yang diperbuat, adalah bertitik tolak dari pandangan bahwa semakin berat atau besar tindak pidana yang diperbuat akan semakin lama ingatan orang atau masyarakat terhadap kejadian itu, yang juga artinya ialah lamanya penderitaan yang dirasakan orang dan atau masyarakat sebagai akibat dari diperbuatnya tindak pidana bergantung dari berat ringannya macam dan jenis tindak pidana yang diperbuat orang. Semakin berat tindak pidana diperbuat akan semakin lama penderitaan yang dibawa oleh orang atau masyarakat sebagai akibat dari perbuatannya tindak pidana. ${ }^{16}$

\footnotetext{
${ }^{14}$ Adami Chazawi, Pelajaran Hukum Pidana Bagian 2, 173-176.

${ }^{15}$ Ibid., 176.

${ }^{16} \mathrm{lbid}$.
} 
Apabila tenggang daluwarsa hapusnya kewenangan menuntut pidana diperbandingkan dengan tenggang daluwarsa hapusnya kewenangan menjalankan pidana (pasal 84), maka jelas lamanya tenggang daluwarsa hapusnya kewenangan menuntut pidana ini lebih pendek. Perbedaan itu adalah wajar dan logis, sebab pada lamanya tenggang daluwarsa hapusnya kewenangan menjalankan pidana si pembuat telah secara pasti (kepastian hukum) bersalah dan telah dijatuhinya pidana oleh pengadilan. Sedangkan pada tenggang daluwarsa hapusnya hak penuntutan pidana, si pembuat belum dinyatakan bersalah dengan jatuhnya suatu putusan pemidanaan oleh pengadilan. ${ }^{17}$

Berhubung adanya pemberatan pidana (misalnya pengulangan) maupun pengurangan pidana (misalnya pembuat belum berumur 18 tahun), maka timbul kesulitan untuk menentukan apakah suatu kejahatan itu diancam dengan pidana penjara paling lama 3 tahun atau lebih dari 3 tahun. Dengan kata lain dalam hal untuk menentukan ancaman pidana penjara paling lama 3 tahun atau lebih dari 3 tahun, apakah pemberatan pidana maupun pengurangan pidana ikut diperhitungkan ataukah tidak perlu diperhitungkan? Misalnya kejahatan pasal 380 KUHP yang diancam pidana penjara 2 tahun 8 bulan, yang apabila terjadi pengulangan maka ancaman pidananya ditambah dengan sepertiganya atau menjadi 3 tahun 6 bulan dan 19 hari. Kesulitannya ialah untuk menentukan tenggang daluwarsa hapusnya kewenangan penuntutan pidana pada pengulangan pasal 380 ini, apakah berpedoman pada ancaman pidana tanpa memperhatikan pemberatan karena pengulangan ( 2 tahun 8 bulan) ataukah memperhitungkan juga pemberatan pada pengulangannya (ditambah sepertiganya) sehingga ancaman pidananya menjadi 3 tahun 6 bulan dan 19 hari? Dengan demikian tenggang daluwarsanya tidak sesudah 6 tahun, tetapi sesudah 12 tahun. Undang-undang tidak memberikan petunjuk mengenai persoalan ini. Mengenai persoalan ini ada 2 pendapat yang saling bertentangan, ${ }^{18}$ yaitu:

a. Pendapat pertama, Noyon, Van Hattum dan Hazewinkel Suringa menyatakan bahwa dalam hal menentukan suatu kejahatan diancam dengan pidana penjara paling lama tiga tahun atau lebih dari tiga

\footnotetext{
${ }^{17} \mathrm{lbid}$.

${ }^{18}$ Jonkers, Hukum Pidana Hindia Belanda, Terj. Tim Penerjemah Bina Aksara (Jakarta: PT Bina Aksara, 1987), 238.
} 
tahun, tidaklah perlu memperhatikan pemberatan pidana ataupun pengurangan pidana, yang harus diperhatikan hanyalah sanksi pidana yang diancamkan pada masing-masing rumusan tindak pidana yang bersangkutan.

b. Pendapat kedua, sebaliknya seperti Jonkers menyatakan bahwa tenggang daluwarsa itu adalah didasarkan pada ancaman pidana maksimum tindak pidana yang pada kenyataannya diperbuat, oleh karena itu keadaan obyektif maupun subyektif yang memberatkan pidana atau meringankan pidana juga harus diperhitungkan dalam hal menentukan tenggang daluwarsa hapusnya kewenangan penuntutan pidana.

Adami Chazawi lebih condong pada pendapat kedua, dengan alasan berikut; Berdasarkan kenyataan bahwa tidak ada penjelasan ataupun keterangan dalam Undang-undang dalam hal memperhitungkan tenggang daluwarsa hapusnya kewenangan penuntutan pidana terhadap pemberatan ataupun peringanan pidana pada kejahatan. Sedangkan menurut pasal 86 KUHP di mana menyatakan bahwa apabila disebut kejahatan maka disitu termasuk percobaannya dan pembantuan, kecuali ditentukan lain, yang artinya Undang-undang hanya memberi penjelasan tentang memperhitungkan tenggang daluwarsa hapusnya kewenangan penuntutan pidana bagi pembantuan kejahatan dan percobaan kejahatan adalah disamakan dengan si pembuat dan si pembuat kejahatan selesai. Oleh karena itu di luar apa yang diterangkan oleh pasal $86 \mathrm{KUHP}$ (in casu pemberat pidana dan peringan pidana pada kejahatan) tetap diperhitungkan dalam hal menentukan tenggang daluwarsa hapusnya kewenangan menuntut pidana. Sebab apabila maksud pembentuk Undang-undang agar tidak diperhitungkan terhadap pemberatan dan atau peringanan pidana, tentulah diberikan keterangan sebagaimana halnya bagi pembantuan kejahatan dan percobaan kejahatan seperti pada pasal 86 KUHP tersebut. ${ }^{19}$

Sedangkan sejak kapan berlakunya tenggang daluwarsa hapusnya kewenangan penuntutan pidana itu, ditetapkan secara umum (pasal 79 KUHP), yaitu pada hari sesudah dilakukannya perbuatan, kecuali dalam tiga hal, ${ }^{20}$ yaitu:

\footnotetext{
${ }^{19} \mathrm{Ibid} ., 176$.

${ }^{20}$ Andi Hamzah, KUHP dan KUHAP(Jakarta: PT Rineka Cipta, 2000), 35.
} 
a. mengenai pemalsuan atau perusakan mata uang, adalah pada hari sesudah barang yang dipalsu atau mata uang yang dirusak itu digunakan;

b. mengenai kejahatan dalam pasal-pasal: 328, 329, 330 dan 333 KUHP, dimulainya adalah pada hari sesudah orang yang langsung terkena kejahatan (korban) dibebaskan atau meninggal dunia;

c. mengenai pelanggaran dalam pasal 556 KUHP sampai dengan pasal 558a KUHP, adalah dimulai pada hari sesudah daftar-daftar yang memuat pelanggaran-pelanggaran itu telah disampaikan/diserahkan pada Panitera Ppngadilan yang bersangkutan.

Berjalannya waktu penghitungan lamanya tenggang daluwarsa, dapat dihentikan oleh adanya tindakan penuntutan, asalkan penuntutan ini diketahui oleh orang yang dituntut atau telah diberitahukan kepadanya menurut cara yang ditentukan Undang-undang. Setelah jalannya tenggang daluwarsa dihentikan oleh adanya penuntutan ini, maka dimulainya lagi tenggang daluwarsa yang baru (pasal $80 \mathrm{KUHP}$ ). Yang dimaksud dengan tindakan penuntutan adalah tindakan Pejabat Penuntut Umum yang menyerahkan berkas perkara pidana ke pengadilan yang disertai dengan permintaan agar perkara itu diperiksa dan diputus (pasal 1 ayat 7 KUHAP). Jadi terbitnya hitungan hari penuntutan ialah pada hari di mana Jaksa Penuntut Umum (JPU) menyerahkan (berkas) perkara yang bersangkutan ke pengadilan yang berkompetensi. Tindakan Penyidik melakukan penyidikan tidak termasuk pengertian penuntutan, dan oleh karenanya tindakan penyidikan tidak menghentikan berjalannya proses tenggang daluwarsa hapusnya kewenangan menuntut pidana. ${ }^{21}$

$\mathrm{Di}$ samping proses berjalannya tenggang daluwarsa dapat dihentikan (dengan tindakan penuntutan), berjalannya tenggang daluwarsa dapat pula tertunda berhubung dengan adanya penundaan (schorsing) penuntutan, yakni apabila terjadi "perselisihan yang harus diputuskan lebih dahulu"/pra-yudisial (pasal 81 KUHP). Tertundanya proses berjalannya tenggang daluwarsa karena adanya penundaan penuntutan berhubung adanya perselisihan pra-yudisial (perselisihan

${ }^{21}$ R. Tresna, Azas-Azas Hukum Pidana (Jakarta: PT Tiara Limit, 2006), 27. 
yang harus diputuskan lebih dahulu) berbeda dengan penghentian berjalannya tenggang daluwarsa karena penuntutan pidana. ${ }^{22}$

Perbedaan itu ialah pada penghentian tenggang daluwarsa karena adanya penuntutan, maka setelah tenggang waktu itu dihentikan akan dimulai penghitungan yang baru lagi, tanpa memperhitungkan lamanya waktu sebelum tenggang daluwarsa dihentikan, artinya waktu yang berjalan sebelum penuntutan dihentikan tidak diperhitungkan lagi. Misalnya A melakukan pencurian tanggal 1 Januari 2001, pada tanggal 2 Januari mulai berjalan hari pertama penghitungan tenggang daluwarsa hapusnya kewenangan penuntutan pidana. Pada tanggal 30 Juni 2001 (berkas) perkara yang bersangkutan oleh Jaksa PU dilimpahkan ke pengadilan yang berwenang, maka terhentilah penghitungan tenggang daluwarsa pada tanggal 30 Juni 2001. Penghitungan tenggang daluwarsanya mulai hari pertama lagi pada keesokan harinya tanggal 1 Juli $2001 .^{23}$

Tetapi pada tertundanya jalan tenggang daluwarsa karena schorsing penuntutan pidana karena adanya perselisihan pra-yudisial itu diselesaikan, maka perhitungan tenggang daluwarsa dilanjutkan lagi, yang artinya lamanya tenggang daluwarsa sebelum terhenti juga turut dihitung. Misalnya pada contoh di atas tadi, berhubung adanya perselisihan pra-yudisial di mana terdakwa mendalilkan barang yang diambilnya itu adalah miliknya sendiri karena telah dibelinya dari si pelapor, maka Majelis Hakim melakukan tindakan schorsing penuntutan pada tanggal 1 Qktober 2001 (sebelumnya tenggang daluwarsa telah berjalan sejak tanggal1 Juli $=3$ bulan). Kemudian, berhubung telah adanya putusan perdata yang mempunyai kekuatan hukum tetap tentang kepemilikan obyek barang yang dalam dakwaan telah dicuri oleh A, maka schorsing penuntutan dicabut dengan dibukanya persidangan kembali pada tanggal 30 Desember 2001. Dengan demikian penghitungan pada tanggal 30 Desember 2001 jalannya tenggang daluwarsa dilanjutkan lagi dengan tetap menghitung masa 3 bulan tenggang daluwarsa yang tertunda dahulu. ${ }^{24}$

Penundaan penuntutan pidana karena adanya perselisihan $p$ rayudisial, maksudnya adalah tindakan penghentian sementara

\footnotetext{
${ }^{22}$ Ibid., 177.

${ }^{23} \mathrm{lbid}$.

${ }^{24} \mathrm{lbid}$
} 
pemeriksaan suatu perkara pidana oleh Majelis Hakim yang memeriksa berhubung diperlukan adanya putusan Majelis perkara yang lain yang sangat penting dan menentukan $\mathrm{dalam}$ hal memutus perkara yang dischorsing tersebut. Jonkers memberi co $\mathrm{n}$ to $\mathrm{h}$ seorang dituntut (diajukan ke sidang pengadilan) dengan didakwa melakukan pencurian suatu barang milik orang lain. Tetapi di persidangan dia memberikan keterangan bahwa barang itu adalah miliknya sendiri. ${ }^{25}$

Apabila tentang kepemilikan ini terdapat kesukaran dalam hal pembuktiannya, karena Majelis Hakim pidana tidak dibenarkan menetapkan tentang kepemilikan dari barang ini, maka Majelis melakukan tindakan penghentian sementara penuntutan, dan meminta pada orang itu mengajukan gugatan perdata untuk menentukan milik siapa barang yang menurut dakwaan diambil oleh Terdakwa tersebut. Di sini telah terjadi keadaan yang disebut perselisihan pra-yudisial sebagaimana contoh tersebut di atas. ${ }^{26}$

Penghitungan tenggang daluwarsa schorsing oleh sebab adanya perselisihan pra-yudisial, tidak saja disebabkan oleh pentingnya suatu putusan perkara perdata yang menentukan terhadap putusan perkara pidana yang dischorsing, tetapi juga dapat terjadi dalam hal diperlukannya putusan lain dari hakim perkara pidana. Misalnya Jaksa PU telah membawa seseorang ke pengadilan dengan mendakwanya "telah menggunakan surat palsu atau dipalsu" (263 ayat 2), sementara ternyata bahwa terhadap orang yang diduga membuat surat palsu atau memalsu surat itu diperiksa oleh Majelis Hakim yang lain, dengan maksud menghindari adanya dua putusan yang saling bertentangan dalam hal pokok perkaranya ada hubungan yang sangat erat, maka Majelis Hakim yang memeriksa dakwaan menggunakan surat palsu atau dipalsu tadi, perlu mengambil tindakan schorsing penuntutan pidana, dengan menghentikan pemeriksaan perkara itu sampai adanya putusan perkara dengan dakwaan membuat surat palsu atau memalsu surat tadi mempunyai kekuatan hukum tetap. ${ }^{27}$

\footnotetext{
${ }^{25}$ Ibid., 243.

${ }^{26} \mathrm{Ibid}$.

${ }^{27} \mathrm{lbid}$.
} 


\section{Daluwarsa dalam Hukum Islam}

Daluwarsa ialah berlakunya sesuatu waktu tertentu atas keputusan adanya hukuman tanpa dilaksanakannya hukuman tersebut. ${ }^{28}$ Dalam pengertian ini, daluwarsa mempunyai akibat hukum yaitu tidak dapat dilaksanakannya suatu hukuman karena lewatnya waktu. Sebagaimana diketahui bahwa tidak semua perbuatan dapat dikenakan hukuman pada seseorang, demikian pula tidak semua perbuatan dianggap berdosa:

"Telah menggambarkan kepada kami dari Ya'qub bin Ibrahim dari Abdurrahman bin Mahdiy dari Muhammad bin Salamah dari Hammad dari Ibrahim dari al-Aswad dari Aisyah dari Nabi saw bersabda: yang terlepas dari hukuman ada tiga macam: 1. Orang tidur hingga ia bangun, 2. Kanak-kanak hingga ia dewasa, 3.

Orang gila hingga ia berakal dan sembuh". ${ }^{29}$

Hadis di atas menjadi indikator pula bahwa tidak ditulis berdosa suatu perbuatan karena keliru, lupa dan terpaksa. Masalahnya bagaimana dengan suatu perbuatan pidana yang sudah daluwarsa.

Hal-hal yang menyebabkan daluwarsanya hukuman itu ada empat, ${ }^{30}$ yaitu: 1. Paksaan, 2. Mabuk, 3. Gila, dan 4. Di bawah umur. Di bawah ini akan dijelaskan keempat sebab tersebut satu persatu.

1. Paksaan

Hukum paksaan dapat berbeda-beda menurut perbedaan perbuatan yang terjadi. Dalam konteks ini perbuatan-perbuatan tersebut dapat dikelompokkan menjadi tiga kelompok. ${ }^{31}$

a. Perbuatan yang tidak dapat dipengaruhi oleh paksaan sama sekali, artinya perbuatan tersebut tetap dianggap sebagai jarîmah.

b. Perbuatan yang diperbolehkan sama sekali karena adanya paksaan, artinya perbuatan tidak dianggap sebagai jarîmah.

c. Perbuatan yang diperbolehkan sebagai pengecualian, artinya perbuatannya tetap dianggap sebagai jarîmah, tetapi pelakunya tidak dikenakan hukuman.

a) Perbuatan yang tidak dipengaruhi oleh paksaan

\footnotetext{
${ }^{28}$ Ahmad Hanafi, Asas-asas Hukum Pidana Islam, 349.

${ }^{29}$ Al-Imam Abu Abdillah Muhammad Ibnu Yazid Ibnu Majah Al-Qazwini, hadis No. 2817 dalam Mausû'ah Hadis Al-Syarif, 1991-1997, VCR II, Global Islamic Software Company.

${ }^{30}$ Ahmad Wardi Muslich, Pengantar dan Asas Hukum Pidana Islam Fiqih Jinayah (Jakarta:Sinar Grafika, 2004), 117.

${ }^{31} \mathrm{lbid}$.
} 
Perbuatan yang tidak bisa dipengaruhi oleh paksaan sama sekali, meskipun paksaan absolut adalah pembunuhan dan penganiayaan berat, (pemotongan anggota badan, pukulan yang berat, dan sebagainya). Alasannya adalah sebagaimana dalam Surah Al-An'am ayat 151:

Katakanlah: "Marilah kubacakan apa yang diharamkan atas kamu oleh Tuhanmu Yaitu: janganlah kamu mempersekutukan sesuatu dengan Dia, berbuat baiklah terhadap kedua orang ibu bapa, dan janganlah kamu membunuh anak-anak kamu karena takut kemiskinan, Kami akan memberi rezki kepadamu dan kepada mereka, dan janganlah kamu mendekati perbuatan-perbuatan yang keji, baik yang nampak di antaranya maupun yang tersembunyi, dan janganlah kamu membunuh jiwa yang diharamkan Allah (membunuhnya) melainkan dengan sesuatu (sebab) yang benar". (QS. Al-An'am ayat 151) ) $^{32}$

b) Perbuatan yang diperbolehkan karena adanya paksaan

Perbuatan-perbuatan yang termasuk kelompok ini hanya berhubungan dengan masalah makanan dan minuman yang diharamkan, seperti makan bangkai, makan daging babi, minum darah, dan barang- barang yang najis, sedangkan paksaannya bersifat absolut. Makanan- makanan yang telah disebutkan semuanya diharamkan, tetapi kalau keadaannya terpaksa atau dipaksa maka hukumnya dibolehkan. Alasannya adalah firman Allah swt sebagai berikut.

"Mengapa kamu tidak mau memakan (binatang-binatang yang halal) yang disebut nama Allah ketika menyembelihnya, padahal sesungguhnya Allah telah menjelaskan kepada kamu apa yang diharamkan-Nya atasmu, kecuali apa yang terpaksa kamu memakannya. Dan sesungguhnya kebanyakan (dari manusia) benar benar hendak menyesatkan (orang lain) dengan hawa nafsu mereka tanpa pengetahuan. Sesungguhnya Tuhanmu, Dia-lah yang lebih mengetahui orang-orang yang melampaui batas." (QS. Al-An'am: 119). ${ }^{33}$

\footnotetext{
${ }^{32}$ Departemen Agama, Qur'an Surah Al-An'am ayat 151.
}

${ }^{33}$ Ibid., Qur'an Surah Al-An'am ayat 119. 
Dari ayat tersebut jelaslah bahwa makanan yang semula diharamkan dalam keadaan terpaksa hukumnya dibolehkan. Demikian pula halnya orang yang dipaksa. Dengan demikian, baik orang yang terpaksa maupun orang yang dipaksa memakan makanan yang diharamkan, ia tidak dibebani pertanggungjawaban pidana dan perdata. Untuk mengetahui secara rinci tentang perbuatan-perbuatan yang termasuk dalam kelompok ini, perlu dilakukan penelitian terhadap nas-nas yang melarang perbuatan-perbuata tersebut. Kalau perbuatan-perbuatan tersebut dibolehkan dalam keadaan terpaksa (darurat) atau dipaksa, perbuatan tersebut termasuk dalam kelompok ini. Akan tetapi, apabila tidak dibolehkan maka tidak termasuk dalam kelompok ini. $^{34}$

c) Perbuatan yang diperbolehkan sebagai pengecualian

Selain perbuatan-perbuatan yang disebutkan pada bagian pertama dan kedua, paksaan absolut dapat menghapuskan hukuman, baik paksaan materiil maupun paksaan moril ma'nawi walaupun perbuatan yang dilakukan oleh orang yang dipaksa tetap dilarang. Alasan pembebasan hukuman dalam perbuatanperbuatan tersebut adalah bahwa pelaku ketika melakukan perbuatannya tidak mempunyai kehendak (irâdah) dan pilihan (ikhtiyâr) yang sebenarnya, sedangkan dasar pertanggung jawaban itu adalah adanya kehendak (irâdah) dan pilihan (ikhtiyâr). Dengan demikian, sebab dari pembebasan hukuman tersebut berkaitan dengan pribadi orang yang melakukannya, bukan dengan perbuatannya itu sendiri. Itulah sebabnya maka pelaku dibebaskan dari hukuman sedangkan perbuatannya tetap dilarang. ${ }^{35}$

Mengenai pertanggungjawaban perdata yang timbul ak ib at perbuatan tersebut tetap dikenakan kepada pelaku perbuatan tersebut, meskipun ia dibebaskan dari pertanggungjawaban pidana, karena m en urut aturan dan kaidah pokok dalam syariat Islam, jiwa dan harta itu dilind u n g i (ma'shûm) oleh negara. Oleh karena itu, penyerangan terhadapnya dilarang dan alasan-alasan dari syara' tidak dapat menghapuskan $\mathrm{h}$ a $\mathrm{k}$ perlindungan tersebut.

\footnotetext{
34 Ibid., 117.

35 Ibid., 117.
} 
Jarîmah yang termasuk dalam kelom pok ketiga ini, antara lain seperti qazdaf (penuduhan zina), peng hin a $n$, pencurian, merusak harta milik orang lain, zina, dan seb a ga in y a..$^{36}$

Muhammad Al-Khudhari banyak memberikan definisi paksaan sebagai berikut;

Paksaan adalah mendorong orang lain atas sesuatu yang tidak diridainya, baik berupa ucapan atau perbuatan.Sebagian fuqaha sebagaimana dikutip oleh Abdul Qadir Audah, memberikan definisi sebagai berikut: ${ }^{37}$ Paksaan adalah suatu perbuatan yang dilakukan oleh seseorang karena orang lain, dan oleh karena itu hilanglah karenanya atau tidak sempurna pilihannya. A tau paksan adalah suatu perbuatan yang timbul dari orang yang memaksadan menimbulkan pada diriorang yang dipaksa suatu keadaan yang mendorong dirinya untuk mengerjakan perbuatan yang dim intakan kepadanya. A tau paksan adalah ancaman oleh seseorang atas orang lain dengan sesuatu yang tidak disenangi untuk mengerjakan sesuatu sehinggakarenanya hilang kerelaannya. ${ }^{38}$

Sebagian fuqaha yang lain mengemukakan definisi sebagai berikut: paksaan adalah sesuatu yang ditimpakan kepada orang lain yang membahayakannya atau menyakitinya". Sebagian lagi berpendapat bahwa definisi paksaan, adalah paksaan adalah ancaman berupa hukuman segera dari orang yang memaksa yang mampu untuk melaksanakan paksaannya dan karenanya mempengaruhi orang berakal sehat untuk mengerjakan apa yang dipaksakan padanya serta timbul dugaan kuat pada dirinya bahwa ancaman tersebut akan benar-benar dikenakan padanya, apabila ia menolak apa yang dipaksakan kepadanya. ${ }^{39}$

Dari definisi-definisi yang dikemukakan di atas dapat $\mathrm{d}$ ia $\mathrm{m} b$ il intisari bahwa paksaan adalah suatu upaya yang dilakukan oleh sese orang untuk mempengaruhi orang lain agar ia melakukan apa yang diinginkan olehnya (pemaksa) dengan menggunakan ancaman. Sebagai akibat $\mathrm{dari}$ adanya ancaman tersebut, pihak yang dipaksa tidak mempunyai pilih an lain, kecuali mengerjakan

\footnotetext{
${ }^{36} \mathrm{lbid}$.

${ }^{37}$ Muhammad Khudhari Bik, Ushûl al-Fiqh (Beirut: DarAl-Fikri,1981), 105.

${ }^{38}$ Abd al-Qadir Audah, al-Tasyrî' al-Jinâ'iy al-Islâmiy, Juz I (Mesir: Dar al-Fikr al-Araby, tth.), 563.

39 Ibid., .563.
} 
apa yang diinginkan oleh pihak yang $m$ emaksa. Itulah sebabnya orang yang dipaksa kehilangan kerelaan (ridha) dan pilihan $(\text { ikhtiy âr })_{.}^{40}$

Tampaknya para fuqaha sama pandangannya bahwa semua jarîmah dapat dipengaruhi oleh paksaan, kecuali jarîmah pembunuhan dan penganiayaan berat. Kedua jarîmah tersebut sangat berbahaya dan menyangkut keselamatan manusia, sedangkan memperlunak hukuman akan menimbulkan bahaya yang sangat besar bagi masyarakat. Para fuqaha berbeda pendapat mengenai jenis hukuman yang harus dijatuhkan kepada pelaku (orang yang dipaksa). Menurut Imam Malik dan Imam Ahmad hukumannya adalah sama dengan pembunuhan sengaja, yaitu qishâsh, karena sudah cukup jelas dan tidak ada syubhat. Sedangkan menurut ulama Syafi'iyah dan Hanafiah, sebagian menyatakan hukumannya adalah qishâsh dan sebagian lagi menyatakan hukumannya adalah diyat. Alasan golongan kedua ini adalah karena adanya paksaan itu dianggap sebagai syubhat yangdapat menghapuskan hukuman qishash. Imam Abu Hanifah sendiri dan muridnya Imam Muhammad ibn Hasan, hanya menetapkan hukuman ta'zîr. ${ }^{41}$

2. Mabuk

Syariat Islam melarang minuman keras, baik sampai mengakibatkan mabuk maupun tidak. Dalam kelompok jarîmah, minuman keras (syurb al-khamr) termasuk jarîmah hudûd yang ancamannya adalah delapan puluh kali cambukan. Kecuali Imam Abu Hanifah dan murid-muridnya, para Ulama telah sepakat semua jenis minuman yang memabukan, baik disebut khamar atau bukan, sedikit atau banyak, hukumnya tetap dilarang dan peminumnya dikenakan hukuman. Akan tetapi, menurut Imam Abu Hanifah dalam hal ini harus dibedakan antara khamar dengan minuman keras yang lain. Untuk minuman, khamar sedikit atau banyak, baik mabuk atau tidak, tetap dihukum, sedangkan untuk minuman keras selain khamar, baru dihukum apabila sampai memabukan. Bahan minuman khamar itu adalah

\footnotetext{
40 lbid., 563.

41 Abd. Al-Rahman Al-Jaziri, Al-Fiqh 'alâ al-Mazâhib al-Arba'ah, Juz V (Beirut: Dar Al- Fikr), 288292.
} 
perasan anggur yang diperas sampai kemudian hilang kurang dua pertiganya. ${ }^{42}$

Secara umum yang dimaksud dengan mabuk adalah hilangnya akal sebagai akibat minum minuman keras atau khamar atau yang sejenisnya. Menurut Imam Abu Hanifah, seorang dikatakan mabuk, apabila ia telah kehilangan akal pikirannya, baik banyak atau sedikit, ia tidak dapat membedakan antara langit dengan bumi, dan antara laki-laki dengan perempuan. Sedangkan Muhammad ibn Hasan dan Imam Abu Yusuf berpendapat bahwa orang mabuk itu adalah orang yang banyak mengigau pada pembicaraannya. Pendapat ini juga merupakan pendapat imamimam yang lain. ${ }^{43}$ Alasan mereka ini adalah firman Allah dalam Surah al-Nisa' ayat 43.

"Hai orang-orang yang beriman, janganlah kamu shalat, sedang kamu dalam keadaan mabuk, sehingga kamu mengerti apa yang kamu ucapkan, (jangan pula hampiri mesjid) sedang kamu dalam keadaan junub, terkecuali sekedar berlalu saja, hingga kamu mandi. dan jika kamu sakit atau sedang dalam musafir atau datang dari tempat buang air atau kamu telah menyentuh perempuan, kemudian kamu tidak mendapat air, maka bertayamumlah kamu dengan tanah yang baik (suci); sapulah mukamu dan tanganmu. Sesungguhnya Allah Maha Pema'af lagi Maha Pengampun." (QS.Al-Nisaa': 43). ${ }^{44}$

Dari ayat tersebut jelaslah bahwa orang yang tidak mengetahui apa yang dikatakannya berarti ia sedang mabuk. Adapun pertanggung jawaban pidana bagi orang yang mabuk, menurut pendapat yang kuat (râjih) dari ulama mazhab yang empat, ia tidak dijatuhi hukuman atas jarîmah-jarîmah yang dilakukannya, apabila ia dipaksa atau terpaksa untuk minum atau ia meminumnya atas kehendak sendiri, tetapi ia tidak mengetahui bahwa yang diminumnya itu adalah khamar atau ia meminumminuman keras untuk berobat, lalu ia mabuk. Orang yang sedang mabuk tersebut ketika ia melakukan perbuatannya, sedang hilang akal pikiran dan kesadarannya, sehingga dengan demikian maka

\footnotetext{
$42 \mathrm{lbid}$.

${ }^{43} \mathrm{lbid}$

${ }^{44}$ Departemen Agama, Qur'an Surah Al-Nisa' ayat 43.
} 
hukumnya sama dengan orang gila. Akan tetapi, jika seseorang minum minuman keras karena kemauan sendiri dengan sengaja tanpa alasan, atau ia meminumnya sebagai obat yang sebenarnya tidak diperlukan kemudian ia mabuk, dalam hal ini ia harus bertanggung jawab atas setiap jarîmah yang dilakukannya ketika ia mabuk. Hukuman tersebut diberikan kepadanya sebagai pengajaran, karena ia telah menghilangkan akalnya sendiri secara sengaja. ${ }^{45}$

Di samping pendapat yang kuat (râjih) tersebut, di kalangan ulama mazhab yang empat ada pendapat yang tidak kuat (marjuh) yaitu bahwa orang yang mabuk tidak dibebani pertanggungjawaban atas semua perbuatan jarîmah yang dilakukannya, bagaimanapun terjadinya dan apapun sebab mabuknya itu, karena pada saat itu akar pikirannya sedang hilang. Ini berarti orang yang mabuk tersebut tidak menyadari perbuatanya, sedangkan kesadaran merupakan dasar adanya pertanggungjawaban pidana. $^{46}$ Mengenai pertanggungjawaban perdata orang yang mabuk tetap dikenakan, sebab jiwa dan harta orang lain tetap harus dijamin keselamatannya dan pembebasan dari hukuman pidana tidak mempengaruhi hukuman perdata. ${ }^{47}$

3. Gila

Syariat Islam memandang seseorang sebagai orang mukallaf yang dapat dibebani pertanggungjawaban pidana, apabila ia memiliki kemampuan berpikir dan memilih (idrâk dan ikhtiyâr). Apabila salah satu dari kedua perkara ini tidak ada maka pertanggungjawaban menjadi terhapus. Kemampuan berpikir seseorang itu dapat hilang karena faktor bawaan sejak lahir atau karena adanya gangguan seperti sakit atau cacat fisik. Hilangnya kemampuan berpikir tersebut dalam bahasa sehari-hari disebut gila. Abdul Qadir Audah memberikan definisi gila sebagai berikut. Menurut beliau "gila adalah hilangnya akal, rusak, atau lemah". 48

Definisi tersebut merupakan definisi yang umum dan luas, sehingga mencakup gila (junûn), dungu (al-'ithu), dan semua jenis

\footnotetext{
${ }^{45}$ A. Hanafi, Asas-Asas Hukum Pidana Islam, 373.

${ }^{46} \mathrm{Ibid} ., 373$

${ }^{47} \mathrm{lbid}$.

${ }^{48}$ Ibid., 564 .
} 
penyakit kejiwaan yang sifatnya menghilangkan idrak (kemampuan berpikir).

Pengaruh gila terhadap pertanggungjawaban pidana tidak sama, tergantung apakah gilanya itu menyertai jarîmah atau sesudahnya:

a. Hukum gila yang menyertai jarîmah

Apabila gila menyertai perbuatan jarîmah (yaitu ketika melakukan jarîmah pelaku sudah gila), maka pelakunya dibebaskan dari pertanggungjawaban pidana, karena pada saat melakukan jarîmah ia tidak mempunyai kekuatan berpikir. Keadaan gila ini tidak menjadikan suatu jarîmah dibolehkan, melainkan hanya menghapuskan hukuman dari pelakunya. Ketentuan ini sudah merupakan kesepakatan para fuqaha dan juga para sarjana hukum positif. Dalam Pasal $44 \mathrm{KUHP}^{49}$ dinyatakan:

(1)Tiada dapat dipidana barangsiapa mengerjakan suatu perbuatan yang tidak dapat dipertanggungjawabkan kepadanya, sebab kurang sempurna akalnya atau sakit berubah akal.

(2) Jikanyata perbuatan itu tidak dapat dipertanggungjawabkan padanya sebab kurang sempurna akalnya atau sakit berubah akal, maka dapatlah hakim memerintahkan memasukkan dia kerumah sakit jiwa selama-lamanya satu tahun untuk diperiksa. $^{50}$

Akan tetapi pembebasan orang gila dari hukuman, tidak berarti ia dibebaskan juga dari pertanggungjawaban perdata, se $b a b$ harta benda dan jiwa orang lain dijamin keselamatannya oleh syara' dan alasan-alasan yang sah tidak dapat menghilangkan ja $\mathrm{m}$ in a n tersebut. Sebagaimana orang gila masih tetap memiliki harta benda,ia juga dapat dibebani pertanggungjawaban perdata, yaitu pertanggungjawaban yang berkaitan dengan harta. Meskipun para fuqaha sepakat mengenai adanya pertanggungjawaban perdata yangpenuh atas orang gila sebagai akibat perbuatannya, $n$ a $\mathrm{m}$ u $\mathrm{n}$ mereka berbeda pendapat mengenai

\footnotetext{
${ }^{49}$ M. Boediarto-K. Wantjik Saleh, Kitab Undang-Undang Hukum Acara Pidana, (Jakarta: Ghalia Indonesia, 1982), 23.

${ }^{50} \mathrm{lbid}$.
} 
sejauh mana b e sarn y a pertanggungjawaban tersebut dalam jarîmah pembunuhan $d$ an penganiayaan.

Perbedaan tersebut berpangkal pada perbedaan pendapat mereka tentang kesengajaan orang gila, apakah dianggap sengaja dalam arti yang sesungguhnya atau dianggap sebaga i kekeliruan semata-mata. Menurut Imam Malik, Imam $A b u$ Hanifah, dan Imam Ahmad perbuatan sengaja dari orang gila itu termasuk tidak sengaja (khatha), karena ia tidak mungkin melakukan perbuatan itu dengan niat yang sesungguhnya. Sedangkan menurut Imam Syaf'i, perbuatan sengaja dari orang gila termasuk kesengajaan dan bukan kesalahan, karena gila itu hanya membebaskan hukuman, tetapi tidak mengubah sikap perbuatannya. ${ }^{51}$

Perbedaan pendapat tentang status perbuatan orang gila tersebut berpengaruh terhadap penggantian kerugian yang harus dipikulnya. Hal ini oleh karena diat pada jarîmah sengaja adalah diyat mughallazah (yang diperberat) dan harus ditanggung sendiri oleh pelaku, sedangkan diat pada jarîmah tidak sengaja (khatha) adalah diat mukhaffafah (yang diperingan) dan ditanggung oleh keluarga ('aqilah) dan pelaku bersama-sama. ${ }^{52}$

a) Hukuman gila yang datang kemudian

Gila yang timbul setelah dilakukannya jarîmah, adakalanya sebelum ada keputusan hakim dan adakalanya sesudahnya.

(1) Gila Sebelum Keputusan Hakim

Menurut ulama Syafi'iyah dan Hanabilah, gila yang timbul sebelum ada keputusan hakim tidak dapat menghalangi dan menghentikan pelaksanaan pemeriksaan pengadilan. Alasannya adalah karena adanya taklif (kecakapan bertindak) hanya disyaratkan pada waktu melakukan jarîmah. Pandangan tersebut tidak berarti menghina atau meremehkan kedudukan orang gila, karenapemeriksaan pengadilan terhadap mereka yang melakukan jarîmah disertai dengan jaminan-jaminan keadilan yang kuat. Alasan-alasan yang dikemukakan oleh mereka barangkali lebih kuat jika dilihat dari segi logika

${ }^{51}$ A. Hanafi, Asas-Asas Hukum Pidana Islam, 383.

52 lbid. 
dan kenyataan, karena seseorang yang telah melakukan suatu jarîmah sudahsepantasnya dijatuhi hukuman. Kalau ia kemudian menjadi gila, hal itu tidak usah mencegah pemeriksaannya di pengadilan, selama masih ada jalan untuk mengadilinya. Hal ini oleh karena pengaruh gila hanya terbatas kepada ketidak-mampuannya sebagai tertuduh untuk membela dirinya, sedangkan menurut aturan hukum, ketidakmampuan tertuduh untuk membela diri tidak mengurangi atau mencegah pemeriksaan hakim. Orang bisu dan orang yang kehilangan suaranya setelah melakukan jarîmah adalah juga orang-orang yang tidak mampu membela diri, akan tetapi mereka tetap dihadakan kemuka pengadilan. Oleh karena itu, tidak perlu membedakan orang-orang gila dengan orang-orang yang bisu. $^{53}$

Akan tetapi Ulama-ulam Malikiyah dan Hanafiyah berpendapat, bahwa kondidsi gila yang terjadi sebelum ada keputusan hakim dapat menghentikan proses pemeriksaan pengadilan dan menundanya sampai keadaan gilanya itu hilang. Alasan mereka adalah bahwa untuk dijatuhkannya hukuman disyaratka adanya taklif. Syarat ini harus terdapat pada waktu dilakukannya pemeriksaan. Dengan perkataan lain pada waktu diadili pelaku harus tetap menjadi orang mukallaf. Pendirian hukum pidana Mesir dan Perancis sama dengan pendirian fuqaha Malikiyah dan Hanafiyah, hanya saja alasannya yang berbeda. Menurut kedua hukum positif tersebut alasan dihentikannya peradilan orang gila adalah karena ketidakmampuannya untuk membela diri. Sedangkan alasan Malikiyah dan Hanafiyah adalah karena tidak adanya syarat untuk penjatuhan hukuman, yaitu taklif. Dalam Pasal 247 Undang-Undang Hukum Acara Pidana Mesir disebutkan: "Apabila tersangka tidak sanggup membela diri karena ada cacat pada akalnya maka ia tidak boleh diadili sampai kecerdasannya kembali kepada kondisi yang cukup untuk membela diri. Apabila ternyata dengan jelas ketidakmampuannya untuk membela diri di

53 Ibid. 
depan pengadilan maka pemeriksaan terhadap dirinya harus dihentikan, sesuai dengan alasan tersebut di atas. ${ }^{54}$

(2) Gila Sesudah adanya Keputusan Hakim

Apabila sesudah ada keputusan hakim orang yang terhukum menjadi gila maka menurut Imam Syafi'i dan Imam Ahmad, pelaksanaan hukuman tidak dapat dihentikan, kecuali apabila jarîmah adalah jarîmah hudûd, sedang pembuktiannya hanya dengan pengakuan terhukum semata-mata. Hal ini oleh karena dalam jarîmah hudûd terhukum (terdakwa) bisa menarik kembali pengakuannya, baik sebelum dilaksanakannya hukuman maupun sesudahnya. Apabila ia menarik kembali pengakuannya, pelaksanaan hukuman harus dihentikan, karena ada kemungkinan penarikan kembali pengakuannya itu benarbenar keluar dari hatinya dengan tulus. Bagi orang gila, karena ia telah terhalang oleh penyakitnya, sedang ia berhak untuk menarik kembali pengakuannya maka pelaksanaan hukuman harus dihentikan atau ditunda sampai sembuh. Apabila keputusan hakim didasarkan kepada bukti-bukti lain selain pengakuan seperti saksi maka pelaksanaan hukuman tetap harus dijalankan. Dasar pendapat ini adalah bahwa pertanggungjawaban pidana dan hukuman dikaitkan dengan waktu dilakukannya jarîmah, bukan dengan keadaan sesudahnya atau sebelumnya. ${ }^{55}$

Imam Malik berpendapat bahwa keadaan gila dapat menunda pelaksanaan hukuman sampai terhukum sembuh dari gilanya, kecuali apabila hukumannya berupa qishâsh. Menurut sebagian Malikiyah, hukuman qishâsh menjadi gugur dan dan diganti dengan diyat. Akan tetapi menurut sebagian yang lain, dalm keadaan harapan sembuh sangat keci, keputusan terakhir diserahkan kepada keluarga korban. Apabila mereka mengambil (melaksanakan) qishâsh, dan kalau tidak maka mereka boleh mengambil diyat. ${ }^{56}$

${ }^{54}$ Ibid.
${ }^{55}$ Ibid.
56 Ibid. 
Imam Abu Hanifah berpendapat apabila keadaan gila timbul setelah terhukum diserahkan untuk dilaksanakan hukumannya maka hukuman tersebut tidak boleh ditunda. Apabila hukumannya berupa qishâsh dan terhukum menjadi gila setelah diserahkan untuk dieksekusi, hukuman qishâsh diganti dengan diyat dengan menggunakan istihsân. Pendirian tentang ditundanya hukuman untuk orang gila, didasarkan atas dua alasan. ${ }^{57}$

1. Penjatuhan hukuman harus didasarkan atas adanya taklif pada diri terhukum dan hukuman tidak akan terjadi kecuali dengan proses pemeriksaan. Dengan demikian, syarat taklif (kecakapan) harus ada pada waktu pemeriksaan dan keputusan hukuman.

2. Pelaksanaan hukuman atau eksekusi termasuk kelanjutan dari proses peradilan. Apabila syarat taklif harus terdapat pada waktu dilakukannya pemeriksaan oleh hakim, syarat ini juga harus terdapat pada saat dilaksanakannya keputusan hakim, sedang dengan adanya gila maka taklif tersebut menjadi hapus.

\section{Di bawah Umur}

Konsep yang dikemukakan oleh syariat Islam tentang pertanggungjawaban anak di bawah umur merupakan konsep yang sangat baik. Meskipun konsep tersebut telah lama usianya, namun konsep tersebut menyamai teori terbaru di kalangan hukum positif. Hukum Romawi sebagai bentuk hukum positif yang paling maju pada masa turunnya syariat Islam dan yang menjadi dasar hukum-hukum Eropa modern, mengadakan pemisahan antara pertanggungjawaban anak di bawah umur dengan pertanggungjawaban orang dewasa dalam batas yang sangat sempit, yaitu usia tujuh tahun. Dengan demikian menurut hukum romawi, apabila anak-anak telah mencapai umur tujuh tahun ke atas maka ia dibebani pertanggungjawaban pidana. Akan tetapi apabila seorang anak belum mencapai usia tersebut (tujuh tahun), ia tidak dikenakan pertanggungjawaban pidana, kecuali kalau ketika melakukan jarîmah ia mempunyai niatan untuk merugikan orang lain. Dalam hal yang terakhir ini, meskipun ia belum mencapai usia

${ }^{57} \mathrm{lbid}$. 
tujuh tahun, tetap dikenakan pertanggungjawaban pidana. Pandangan hukum Romawi ini tentu saja sangat jauh berbeda dengan konsep yang dibawa oleh syariat Islam. ${ }^{58}$

Menurut syariat Islam, pertanggungjawaban pidana didasarkan atas dua perkara, yaitu kekuatan berpikir (idrâk) dan pilihan (ikhtiyâr). Sehubungan dengan kedua dasar tersebut, maka kedudukan anak di bawah umur berbeda-beda sesuai dengan perbedaan masa yang dilaluinya dalam kehidupannya, semenjak ia dilahirkan sampai ia memiliki kedua perkara tersebut. ${ }^{59}$

Secara alamiah terdapat tiga masa yang dialami oleh setiap orang sejak ia dilahirkan sampai ia dewasa: ${ }^{60}$

1. Masa tidak adanya kemampuan berpikir (Idrâk)

Masa ini dimulai sejak seseorang dilahirkan dan berakhir pada usia tujuh tahun. Pada masa tersebut seorang anak dianggap tidak mempunyai kemampuan berfikir, dan ia disebut anak yang belum tamyîz. Sebenarnya tamyîz atau masa seseorang mulai bisa membedakan antara benar dan salah, tidak dibatasi dengan usia tertentu, karena tamyîz tersebut kadang-kadang bisa timbul sebelum usia tujuh tahun dan kadang-kadang terlambat sesuai dengan perbedaan orang, lingkungan, kondisi kesehatan akal, dan mentalnya. Akan tetapi, para fuqaha berpedoman kepada usia dalam menentukan batas-batas tamyîz dan kemampuan berpikir, agar ketentuan tersebut bisa berlaku untuk semua orang, dengan berpegang kepada keadaan yang umum dan biasa terjadi pada anak. Pembatasan tersebut diperlukan untuk menghindari kekacauan hukum. ${ }^{61}$

Disamping itu pembatasan tamyîz dengan umu $\mathrm{f}$ memungkinkan kepadaseorang hakim untuk mengetahui dengan mudah apakah syarat tersebut (kemampuan berpikir) sudah terdapat atau belum, sebab dengan usia anak lebih mudah un tu k mengetahuinya. Meskipun anak yang belum berusia tujuh tahun sudah menunjukkan kemampuan berpikir, bahkan mungkin melebihi an ak yang sudah berumur tujuh tahun, namun

\footnotetext{
${ }^{58} \mathrm{lbid}$

${ }^{59} \mathrm{lbid}$

${ }^{60}$ Ahmad Wardi Muslich. Pengantar dan Asas Hukum Pidana Islam, 240.

${ }^{61} \mathrm{lbid} ., 240$.
} 
ia tetap dianggap belu m tamyizz, karena yang menjadi ukuran adalah kebanyakan orang $d$ a n bukan perorangan.$^{62}$

Dengan demikian, seorang anak yang belum tamyîz, karena belum mencapai usia tujuh tahun, apabila ia melakukan suatu jarîmah tidak dijatuhi hukuman, baik yang bersifat pidana maupun pendidikan. la tidak dikenakan hukuman had apabila ia melakukan" jarîmah hudûd dan tidak diqishâsh apabila ia melakukan jarîmah qishâsh. Akan tetapi, pembebasan anak tersebut dari pertanggungjawaban pidana tidak menyebabkan ia dibebaskan dari pertanggungjawaban perdata dari setiap jarîmah yang dilakukannya. la tetap diwajibkan membayar ganti rugi yang dibebankan kepada harta miliknya, apabila tindakannya menimbulkan kerugian kepada orang lain, baik pada hartanya maupun jiwanya. ${ }^{63}$

2. Masa kemampuan berpikir yang lemah

Masa ini dimulai sejak seorang anak memasuki usia tujuh tahun dan berakhir pada usia dewasa (balig). Kebanyakan fuqaha membatasi usia balig ini dengan lima belas tahun. Apabila seorang anak telah mencapai usia lima belas tahun maka ia sudah dianggap dewasa menurut ukuran hukum, meskipun mungkin saja ia belum dewasa dalam arti yang sebenarnya. Imam Abu Hanifah menetapkan usia dewasa dengan delapan belas tahun. Menurut satu riwayat sembilan belas tahun untuk laki-laki dan tujuh belas tahun untuk perempuan. Pendapat yang masyhur di kalangan ulama Malikiyah sama dengan pendapat Imam Abu Hanifah. ${ }^{64}$

Pada periode yang keduaini, seorang anak tidak dikenakan pertanggung-jawaban pidana atas jarîmah-jarîmah yang dilakukan baik jarîmah hudûd, qishâsh, maupun ta'zîr. Akan tetapi, ia dapat dikenakan hukuman pengajaran (ta'dîbiyah). Pengajaran ini meskipun sebenarnya berupa hukuman juga, akan tetapi tetap dianggap sebagai hukuman pengajaran dan bukan hukuman pidana. Oleh karena itu, apabila anak tersebut bekali-kali melakukan jarîmah dan berkali-kali pula dijatuhi pengajaran, namun ia tidak dianggap 
sebagai residivis atau pengulang kejahatan. Untuk pertanggungjawaban perdata ia tetap dikenakan, meskipun ia dibebaskan dari pertanggungjawaban pidana, apabila perbuatannya merugikan orang lain, baik hartanya maupun jiwanya. Karena harta dan jiwa dijamin keselamatannya oleh syara' dan alasan-alasan yang sah tidak dapat menghapuskan jaminan tersebut. ${ }^{65}$

3. Masa kemampuan berpikir penuh

Masa ini dimulai sejak seorang anak mencapai usia dewasa, yaitu usia lima belas tahun menurut kebanyakan fuqaha atau delapan belas tahun menurut pendapat Imam Abu Hanifah dan pendapat yang masyhur dari mazhab Maliki. Pada periode ini seoranganak dikenakan pertanggungjawaban pidana atas semua jarîmah yang dilakukannya, apapun jenis dan macamnya. Pada umumnya hukum positif sama pendiriannya dengan syariat Islam, yaitu mengadakan perbedaan pertanggungjawaban pidana menurut perbedaan umur anak-anak di bawah umur. Di samping itu dalam hukum positif, juga anak-anak di bawah umur dikenakan pertanggungjawaban perdata, baik dijatuhi hukuman pidana atau tidak. Hal itu disebabkan karena tidak ada pertentangan antara dibebaskannya dari hukuman karena belum mencapai usia tertentu dengan keharusan mengganti kerugian yang timbul sebagai akibat perbuatannya. ${ }^{66}$

\section{Keniscayaan Hukum Daluwarsa Penuntutan}

Yang dimaksud dengan daluwarsa ialah berlakunya sesuatu waktu tertentu atas keputusan adanya hukuman tanpa dilaksanakannya hukuman tersebut. Dengan berlakunya masa tersebut maka pelaksanaan hukuman menjadi terhalang. Di kalangan fuqaha masih diperselisihkan, apakah daluwarsa dapat menghapuskan hukuman atau tidak. Menurut kebanyakan fuqaha, tidak menghapuskan. Bagi fuqaha yang memakai prinsip daluwarsa tersebut tidak menganggapnya sebagai faktor pembatalan hukuman bagi seluruh jarîmah. ${ }^{67}$ Dalam hal ini ada dua teori:

Teori pertama, dari Imam Malik, Syafi'i dan Ahmad. Menurut teori tersebut sesuatu hukuman atau jarîmah tidak gugur, bagaimanapun

\footnotetext{
${ }^{65} \mathrm{lbid}$.

${ }^{66} \mathrm{lbid}$.

${ }^{67}$ Ahmad Hanafi, Asas-Asas Hukum Pidana Islam, 349.
} 
juga lamanya hukuman atau jarîmah tersebut tanpa dilaksanakan atau diadili, selama bukan berupa hukuman atau jarîmah ta'zir, sebab terhadap hukuman dan jarîmah tersebut berlaku prinsip daluwarsa apabila dipandang perlu oleh penguasa negara untuk mewujudkan kemaslahatan umum. ${ }^{68}$

Dasar teori tersebut ialah bahwa pada aturan-aturan dan n as-n as syari'at Islam tidak ada hal-hal yang menunjukkan hapusnya $h u k u m$ an jarîmah-jarîmah hudûd dan qishâsh-diyat dengan berlakunya masa tertentu. Penguasa negara juga tidak bisa mengampuni atau menggugatkan hukuman tersebut. Kalau tidak ada nas yang menghapuskan, maka artinya tidak bisa hapus dengan adanya daluw a rsa. 69

Pemalsuan tanda tangan ini sendiri termasuk dalam jarîmah ta'zîr, mengenai jarîmah-jarîmah ta'zir, maka penerapan aturan-aturannya yang umum mengharuskan berlakunya prinsip daluwarsa, karena penguasa negara bisa memaafkan jarîmah ta'zir dan hukumannya, artinya memaafkannya dengan segera. Kalau ia bisa memaafkan dengan segera, maka ia juga bisa menggantungkan gugurnya hukuman kepada berlakunya masa tertentu, kalau dengan tindakannya itu bisa diwujudkan kepentingan umum. ${ }^{70}$

Teori kedua, berasal dari Imam Abu Hanifah beserta muridmuridnya. Pada dasarnya pendapat mereka sama dengan pendapat teori pertama, yaitu mengakui adanya prinsip daluwarsa untuk jarîmahjarîmah ta'zîr, jarîmah- jarîmah qishâsh-diyat dan satu jarîmah hudûd, yaitu memfitnah (qadzaf). Menurut Zufar, murid Imam Abu Hanifah, untuk semua hukuman hudûd juga tidak berlaku prinsip tersebut, yang berarti sama dengan teori pertama. ${ }^{71}$

Akan tetapi imam Abu Hanifah sendiri mengakui adanya prinsip daluwarsa untuk jarîmah-jarîmah hudûd selain jarîmah memfitnah. Meskipun demikian, ia mengadakan pemisahan, apakah bukti-bukti penetapan jarîmah-jarîmah hudûd tersebut berupa saksi-saksi ataukah berupa pengakuan pembuat. Kalau alat-alat bukti berupa saksi-saksi, maka hukuman bisa hapus dengan daluwarsa. Tetapi kalau alat-alat

\footnotetext{
${ }^{68} \mathrm{lbid}$.

69 Ibid.

70 lbid.

71 Ibid.
} 
bukti berupa pengakuan pembuat, maka daluwarsa tidak berlaku, kecuali untuk jarîmah minum-minuman keras. ${ }^{72}$

Pemisahan tersebut didasarkan atas pendapatnya tentang persaksian dalam hudûd dan pengaduan korban dalam jarîmah qadzaf, jarîmah hudûd yang ditetapkan berdasarkan persaksian mengalami daluwarsa.Karena persaksian itu bisa mengalami daluwarsa, artinya kalau kesaksian itu diberikan sesudah lewat masa tertentu, maka persaksian tersebut, tidak dapat diterima. ${ }^{73}$

Pada dasarnya setiap orang bisa memberikan persaksiannya seketika mengenai terjadinya jarîmah hudûd. Akan tetapi kalau ia tidak memberikan persaksiannya pada saat itu, maka ada kalanya karena ia tidak ingin mengorek-ngorek keburukan orang lain, kecuali kalau ada halangan benar-benar. Kalau sesudah itu ia memberikan persaksian, maka hal ini menimbulkan dugaan bahwa ia mempunyai kebencian terhadap orang lain tersebut. Oleh karena kebencian itu adalah sesuatu yang tidak nampak dan sukar dibuktikan dalam semua keadaan, maka daluwarsa ditempatkan sebagai gantinya. Berdasarkan ini maka semua persaksian tidak dapat diterima dengan adanya daluwarsa, meskipun boleh jadi tidak ada perasaan terhadap diri saksi itu. ${ }^{74}$

Mengenai jarîmah memfitnah(qadzaf) maka tidak ada daluwarsa, karena dalam jarîmah ini pengaduan korban menjadi syarat adanya tuntutan fihak penguasa. Jadi saksi tidak dapat memberikan keterangannya sebelum ada pengaduan tersebut, sedang untuk jarîmah lain tidak diperlukan. ${ }^{75}$

Kalau imam Abu Hanifah sudah mengakui adanya daluwarsa untuk jarîmah (dituntutnya jarîmah), maka ia menerapkan pula prinsip tersebut untuk hukumannya, karena menurut mereka pelaksanaan hukuman termasuk dalam pemeriksaan pengadilan, artinya pelaksanaan hukuman menjadi penyempurna pengadilan. Jadi pada jarîmah disyaratkan tidak boleh daluwarsa, maka syarat ini juga berlaku pada pelaksanaan hukumannya. ${ }^{76}$

Imam Abu Hanifah sendiri tidak menentukan batas masa daluwarsa dan hal ini diserahkan kepada hakim dengan menimbang pada

\footnotetext{
${ }^{72} \mathrm{Ibid}$

${ }^{73} \mathrm{lbid}$

74 lbid.

$75 \mathrm{lbid}$.

$76 \mathrm{lbid}$.
} 
keadaan yang berbeda-beda. Menurut Muhammad, murid imam Abu Hanifah, masa tersebut adalah enam bulan. Menurut pendapat lain, adalah sebulan. Dengan demikian, maka penguasa negara bisa membuat batas masa daluwarsa dan menolak setiap keterangan (persaksian) yang diberikan sesudah lewat masa tersebut, jika alat-alat buktinya berupa persaksian. ${ }^{77}$

Ringkasnya, menurut imam Abu Hanifah hukuman jarîmah ta'zîr bisa hapus dengan daluwarsa, bagaimanapun juga alat buktinya. Hukuman jarîmah hudûd selain jarîmah memfitnah bisa hapus dengan daluwarsa apabila alat buktinya berupa persaksian. Jika alat buktinya berupa pengakuan, maka hukuman tersebut tidak hapus, kecuali minum-minuman keras maka bisa hapus. ${ }^{78}$

\section{Simpulan}

Dalam hukum Islam, daluwarsa hanya masuk dalam bagian yang menghapuskan hak untuk melaksanakan hukuman. Dengan demikian dalam perspektif hukum pidana Islam, setiap orang yang telah melakukan tindak pidana dan terhadap perbuatan pidana itu belum sampai dijatuhi hukuman, maka meskipun sudah daluwarsa, pidana tidak menjadi hapus. Ini berarti orang yang melakukan tindak pidana kapan waktu saja dapat dituntut atau perkaranya dapat diadili. Sedangkan daluwarsa hanya berlaku manakala tindak pidana yang telah dilakukan seseorang itu telah mendapat putusan hakim sehingga orang tersebut harus menjalani hukuman sebagaimana yang telah dijatuhkan hakim. Namun berhubung daluwarsa maka pelaksanaan hukuman menjadi hapus. Dengan demikian, orang yang telah dijatuhi hukuman itu bebas dari menjalankan hukuman yang telah dijatuhkan. Dalam hukum pidana Islam, daluwarsa hanya bermata satu karena daluwarsa hanya berfungsi menghapuskan pelaksanaan hukuman namun tidak menghapuskan penuntutan pidana. Sedangkan dalam KUHP, daluwarsa bermata dua yaitu dapat menghapuskan hak untuk menuntut pidana juga dapat menghapuskan hak negara mengeksekusi orang yang telah dijatuhi hukuman tersebut.

\footnotetext{
${ }^{77} \mathrm{lbid}$

${ }^{78}$ Ibid.
} 


\section{Daftar Rujukan}

Al-Jaziri, Abd. Al-Rahman. al-Fiqh 'alâ al-Mazâhib al-Arba'ah. Juz V, Beirut: Dar Al- Fikr.

Al-Qazwini, Al-Imam Abu Abdillah Muhammad Ibnu Yazid Ibnu Majah. dalam Mausû'ah al-Hadîts al-Syarîf. 1991-1997, VCR II, Global Islamic Software Company.

Audah, Abd al-Qadir. al-Tasyrî' al-Jinâ'iy al-Islâmiy. Juz I, Mesir: Dar alFikr al-Araby, th.

Bik, Muhammad Khudhari. Ushûl al-Fiqh. Beirut: Dar al-Fikri, 1981.

Boediarto-K. M. dan Wantjik Saleh. Kitab Undang-Undang Hukum Acara Pidana. Jakarta: Ghalia Indonesia, 1982.

Chazawi, Adam. Pelajaran Hukum Pidana Bagian 2. Jakarta: PT Raja Grafindo Persada, 2002.

Hamzah, Andi. KUHP dan KUHAP. Jakarta: PT Rineka Cipta, 2000.

Hanafi, A. Asas-Asas Hukum Pidana Islam. Jakarta: Bulan Bintang, 1990.

Jonkers. Hukum Pidana Hindia Belanda. Terj. Tim Penerjemah Bina Aksara, Jakarta: PT Bina Aksara, 1987.

Kanter, E.Y. dan Sianturi. Asas-Asas Hukum Pidana di Indonesia dan Penerapannya. Jakarta: Alumni, 1982.

Moeljatno. Kitab Undang-Undang Hukum Pidana. Jakarta: Bumi Aksara, 2003.

Muslich, Ahmad Wardi. Pengantar dan Asas Hukum Pidana Islam Fiqih Jinayah. Jakarta: Sinar Grafika, 2004.

Tresna, R. Azas-Azas Hukum Pidana. Jakarta: PT Tiara Limit, 2006. 